УДК 398

ББК $82.3(5$ Япо) 4
ФОЛЬКЛОРНЫЙ МОТИВ

О МИФИЧЕСКОМ ЛЮБОВНИКЕ

В ДРЕВНЕЙ И РАННЕСРЕДНЕВЕКОВОЙ ЯПОНСКОЙ ЛИТЕРАТУРЕ

\author{
(C) 2019 г. А.Р. Садокова \\ Институт стран Азии и Африки \\ МГУ им. М.В. Ломоносова, \\ Москва, Россия \\ Дата поступления статьи: 28 июля 2019 г. \\ Дата публикации: 25 декабря 2019 г.
}

DOI: IO.22455/2500-4247-20I9-4-4-294-3I5

Аннотация: В японской народной культуре издавна большое значение придавалось культу змея, что нашло свое отражение в древних мифологических текстах, произведениях фольклорной прозы, в народных обычаях и обрядах. Наблюдалось обожествление змея, как бога-подателя влаги и хранителя местности. Со змеем в японской традиционной культуре связан фольклорный мотив мифического любовника, широко распространенный также в разных регионах мира. В мифологических и географо-этнографических сводах VIII в. союз змея и женщины воспринимался как божественный, и от этого брака рождались божества, которые были призваны сыграть важную роль в мифологической истории Японии. Однако в средневековом эпосе мотив был переосмыслен. Союзом женщины и змея стали объяснять рождение героя, наделенного большими воинскими способностями. Обращает на себя внимание «тяготение» темы мифического любовника к южным островам Японии и архипелагу Рюкю. Богатый японский материал на тему мифического любовника чрезвычайно важен как для фольклорных типологических обобщений, так и для более глубокого исследования фольклорно-мифологических основ традиционной японской культуры.

Ключевые слова: фольклорный мотив, типологические обобщения, мифический любовник, бог-змей, японские мифологические своды, самурайский эпос.

Информация об авторе: Анастасия Рюриковна Садокова - доктор филологических наук, профессор, Институт стран Азии и Африки, Московский государственный университет им. М.В. Ломоносова, ул. Моховая, д. ІІ, стр.І, І25009 г. Москва, Россия. ORCID ID: о0оо-о0о3-1096-5669

E-mail: sadokova@list.ru

Для цитирования: Садокова А.Р. Фольклорный мотив о мифическом любовнике в древней и раннесредневековой японской литературе // Studia Litterarum. 2019. T. 4, № 4. C. 294-3I5. DOI: IO.22455/2500-4247-20I9-4-4-294-3I5 


\section{FOLKLORE MOTIF OF THE MYTHICAL LOVER IN THE ANCIENT AND EARLY- MEDIEVAL JAPANESE LITERATURE}

This is an open access article

distributed under the Creative

Commons Attribution 4.0

International (CC BY 4.0)

(C) 20I9. A.R. Sadokova

Institute of Asian and African Studies of the Lomonosov

Moscow State University,

Moscow, Russia

Received: July 28, 2019

Date of publication: December 25, 2019

Abstract: Japanese folk culture put great emphasis on the cult of the serpent since the ancient times. This cult found reflection in ancient mythological texts, folklore narratives, and folk customs and rituals. Japanese worshiped the serpent as a God giving rain as well as the guardian of the area. In traditional Japanese culture, the serpent is associated with the folklore motif of the mythical lover widely known in various parts of the world. Mythological as well as geographical and ethnographic records of the $8^{\text {th }}$ century present the union of the serpent and the woman as divine. Gods born out of this marriage played important role in the Japanese mythological history. However, the motif was revised in the medieval epic literature. Now, the woman-and-serpent union resulted in the birth of the hero endowed with great military abilities. The motif of the serpent as the mythical lover was especially widespread in the Southern islands of Japan and Ryukyu Archipelago. Rich Japanese material associated with this theme is extremely important for both typological generalizations in folklore studies and deeper research of the traditional Japanese culture and its mythical foundations.

Keywords: folklore motif, typological generalizations, mythical lover, God-serpent, Japanese mythological records, samurai epic literature.

Information about the author: Anastasya R. Sadokova, DSc in Philology, Professor, Institute of Asian and African Studies of the Lomonosov Moscow State University, Mohovaya II-I, I25009 Moscow, Russia. ORCID ID: 0000-0003-I096-5669

E-mail: sadokova@list.ru

For citation: Sadokova A.R. Folklore Motif of the Mythical Lover in the Ancient and EarlyMedieval Japanese Literature. Studia Litterarum, 20I9, vol. 4, no 4, pp. 294-3I5. (In Russ.) DOI: I0.22455/2500-4247-2019-4-4-294-315 
В японской народной культуре издавна большое значение придавалось культу змея, что нашло свое отражение в древних мифологических текстах, произведениях фольклорной прозы, в народных обычаях и обрядах. Очевидно, что представления о змее, нередко понимаемом как Дракон или иной змееподобный персонаж, получили распространение во всех странах восточноазиатского историко-культурного региона, однако японский материал, источником для которого являются самые разные стороны народной культуры, благодаря своей насыщенности и многообразию может считаться важным звеном для изучения этого культа у народов Восточной Азии.

В японском синтоистском пантеоне Бог-Змей был наделен собственным именем - Хэбигами, что буквально означает «Змеиный бог», и считался богом исцеления, а также защитником дома и рисовых полей. Древние представления о связи змея и культа плодородия отмечались исследователями самых разных культур. Как писал В.В. Иванов, «змей, представленный почти во всех мифологиях, символ, связываемый с плодородием, землей, женской производящей силой, водой, дождем, с одной стороны, и домашним очагом, огнем (особенно небесным), а также мужским оплодотворяющим началом - с другой» [4, с. 468]. Японский материал полностью подтверждает это определение.

Как покровителю земли и богатого урожая в японской традиции змею уделялось особое внимание в период весенних работ. До сих пор в апреле практически повсеместно проводят архаичный обряд встречи просыпающихся после зимней спячки насекомых, змей и лягушек, которые обожествляются и считаются разными ипостасями Бога рисового поля (Taно ками). Этот обряд предполагает торжественную «встречу» насекомых в начале апреля, а змей и лягушек - в конце апреля. Для обряда готовят 
специальное угощение - жареный соевый творог-тофу и выкладывают его в места предполагаемого пробуждения [І8, с. 46г]. В мае, когда начинается посадка риса, змеи повсеместно почитаются как ногами (букв. «Бог поля»), т. е. боги-покровители работ на полях, чаще всего, рисовых. Считается, что в это время они обитают в каждом водоеме и помогают высаживать рассаду на рисовые поля. В эти дни змея чествуют как бога-подателя влаги и богатого урожая [24, с. 847]. То есть на время праздника посадки риса тауэ он выступает в качестве некого единого божества, соединяясь с Богом Драконом - повелителем дождей, Богом воды и Богом рисовых полей и становится некой «материализацией» этих богов, которые в синтоизме не имеют ни антропоморфной, ни зооморфной иконографии.

В периоды, не связанные с полевыми работами, Бог-Змей издавна понимался как защитник жизни деревни, покровитель домашнего очага и даже целитель. Интересно, что в японских деревнях до сих пор весной проводятся охранительные обряды, когда стараются «преградить путь» в деревню разного рода невзгодам, в том числе болезням и бедности. Для этого исстари над дорогой, ведущей в деревню, вывешивали особым образом сплетенную рисовую веревку-симэнава. Вариантов «закрытия пути» при помощи соломенной веревки по всей Японии насчитывается довольно много: это и изготовление соломенной куклы-великана, и нанизывание на соломенную веревку бусин, но главное - плетение огромного соломенного змея, который своим видом должен напугать несчастья и прогнать их прочь [20, с. 453; 22, с. 32-45]. Кроме того, в Японии в ряде мест до сих пор сохраняется обычай строить для змея домик хэбимия (букв. «змеиный храм»). Это небольшое каменное или глиняное сооружение, напоминающее по своему виду синтоистскую кумирню. Там, как полагают, обитает Бог-Змей - защитник дома, потому само сооружение воспринимается как важный оберег [18, с. 463].

Однако было бы неверно полагать, что в японской традиционной культуре сложилось однозначно положительное отношение к змеям и что японцы их совсем не опасались. Это, конечно, не так. Фольклорные тексты, в основном локальные легенды буддийских храмов, дают множество примеров восприятия змея как вредоносного начала. Змей в народном буддизме, в отличие от синтоизма, однозначно выступал «на стороне зла», но мог быть побежден силой буддийского Учения или увещеваниями со стороны буддийского настоятеля. 
Достаточно в этой связи вспомнить легенду старого буддийского храма Китаин в г. Кавагоэ (преф. Сайтама). В ней речь идет о запрете звенеть колокольчиком на территории храма. Рассказывают об одном настоятеле, который однажды спас змею, которую мучили дети. Он принес ее в храм, где она и пребывала, пока не стала приносить беды. Тогда настоятель убедил ее уползти из храма и вернуться только по звуку колокольчика. С тех пор, рассказывают, и появился запрет звенеть колокольчиками на территории храма Китаин [23, с. 8].

Примеров подобного рода в японском фольклоре, особенно среди буддийских легенд, можно обнаружить много. Но привычка жить в стране, где обитают змеи, а также сложившееся исстари на основе синтоистских представлений их обожествление, как богов-подателей влаги и хранителей местности или дома, привело к амбивалентности образа, в котором «позитивное» в народном сознании даже стало преобладать над «негативным».

В этой связи, как отражение исконного отношения японцев к змеям, интересной представляется тема мифического любовника, известная в фольклоре многих народов мира. В японской традиции она не только получила широкое распространение, но и способствовала созданию самых разных по сюжету народных повествований, а также проникла в произведения японской древней и средневековой литературы. В японской традиции в реализации этой темы просматриваются типологические черты, но можно говорить и о собственно японской специфике.

Народные повествования разных народов о мифическом любовнике в большей или меньшей степени имеют схожий сюжет и тяготеют к мотиву «Мифическое существо вступает (пытается вступить) в любовные отношения с девушкой (женщиной)». Исследователь восточнославянских быличек о мифическом любовнике Н.К. Козлова в работе «Восточнославянские былички о змее и змеях» отмечает: «Исконным персонажем в этой тематической группе, на наш взгляд, является огненный змей. Однако в роли любовника женщины в быличках выступают черт, покойник, леший, домовой, водяной» [5].

Для японской народной традиции все перечисленные персонажи, кроме змея, но не обязательно огненного, в контексте данного мотива не характерны. Истории же о змее, который в облике прекрасного мужчины посещает по ночам женщину, представлены широко. Это свидетельствует об устойчивом сохранении архаических синтоистских представлений о связи змея с 
плодородием, влагой, продолжением рода. Характеризуя образ змея в восточнославянской традиции, в той же своей работе Н.К. Козлова дает такую характеристику этому персонажу: «Змей - очень древний и сложный образ; он связан со стихиями огня и воды; с небом, дарующим земле дождь; с самой землей и ее плодородием; с подземными пещерами и их богатствами; с культом предков. Но в то же время может вступать в отношения с живыми людьми, принимая человеческий облик» [5]. Это определение в полной мере соответствует и древним японским народным представлениям о змее.

Интересно, что тема мифического любовника, который на самом деле оказывается змеем, широко была представлена в первых письменных памятниках Японии VIII в. Каждый из этих памятников играл в период своего создания важную роль в деле укрепления японской государственности, но при этом был тесно связан с народной традицией, широко использовал фольклорный материал. Можно даже сказать, что столь значимые для японской истории и культуры мифологические своды, как «Кодзики» («Записи о деяниях древности», 7І2 г.) и «Нихон сёки» («Нихонги») («Анналы Японии», 720 г.), а также географо-этнографические записи разных провинций фудоки, созданные в первой половине VIII в., и даже поэтическая антология «Манъёсю» («Собрание мириад листьев», середина VIII в.), в значительной степени являются фольклорными источниками, сохранившими огромное количество древних фольклорных мотивов и сюжетов, восходящих к архаическим воззрениям японцев [7; 8; II; 3; 9].

Если учесть, что в синтоистской традиции змей воспринимался как божество плодородия и податель влаги, то присутствие историй о нем в древних памятниках, во многом восходящих к японской народной традиции, не кажется странным. Более того, наличие этих историй, а иногда и нескольких, буквально в каждом из перечисленных памятников свидетельствует о широком распространении темы мифического любовника-змея в древнем японском фольклоре.

Тематически истории о змее в первых японских письменных памятниках можно отнести к двум группам: повествования о змееборстве и собственно рассказы о мифическом любовнике. Отметим, что тема змееборства встречается там дважды. Прежде всего, это широко известный эпизод из «Кодзики» о борьбе бога Сусаноо-но микото с восьмиглавым и восьмихвостым змеем Ямата-но ороти. А также эпизод из географо-этнографического 
свода фудоки провинции Хитати - «Хитати-фудоки» (между 7І4 и 7І8 гг.) о борьбе некого Матати из рода Яхадзу, который, расчистив поля для урожая, вступил в схватку со «злым богом»-змеем Яцу-но ками. В свое время В.Я. Пропп, подробно рассматривая мотив змееборства в русских былинах, отмечал, что «змееборство - один из самых распространенных сюжетов мирового фольклора. Но каждый народ, в зависимости от эпохи и от особенностей своей национальной культуры и своей исторической борьбы, вкладывает в этот сюжет свой смысл и придает ему свою национальную форму». Далее же В.Я. Пропп писал, что «борьба с чудовищами ведется теми героями, которые на позднейших ступенях развития эпоса будут главнейшими и лучшими воинскими героями...» [16, с. I82-I83]. Не вдаваясь сейчас в подробности эпизодов, связанных со змееборством в японской традиции, отметим лишь, что оба названных японских героя-змееборца прославились как герои-созидатели, и этим своим подвигом определили дальнейшее развитие японской истории и культуры. Сусаноо-но микото, убив змея, стал, по сути, правителем страны Изумо, отвоевал ее таким образом у «сил зла». А смельчак Матати из рода Яхадзу, разогнав змей, защитил поля для всей земледельческой общины, тем самым способствуя плодородию земель и процветанию края. Затем он объявил змею Яцу-но ками «границы дозволенного», провозгласив при этом того божеством, которому будут поклоняться люди [7, с. 59-6о; 3, с. 42].

Обратим внимание, что именно такая «расправа» со змеем, т. е. не убиение, а договоренность более характерна для синтоистских представлений о божественном статусе змея, о чем речь шла ранее. И хотя в эпизоде из «Хитати-фудоки», Матати из рода Яхадзу, «поубивал и разогнал» небольших змей, затем он вступил в диалог с главным змеем. Матати подошел в подошве горы и на пограничном рву в качестве вехи установил большой шест. И после этого произнес, обращаясь к змею Яцу-но ками: «Все, что выше этого места, пусть будет владением бога, а все, что ниже, - пусть будет землей людей. Отныне и впредь я буду твоим жрецом и буду вечно почитать тебя. Я прошу тебя, не посылай на нас несчастья и не гневайся» (пер. К.А. Попова). Затем герой воздвиг там храм и совершил моление [3, с. 42]. Элементы змееборства можно обнаружить и в следующем эпизоде «Хитати-фудоки». Там повествуется о потомках смельчака Матати, а именно о неком Маро, который решил вырыть пруд, но поглядеть на его работу явился тот самый змей Яцу-но ками «со своими подручными». Они взобра- 
лись на дубы и не уходили. Тогда Маро закричал, что люди будут убивать всех зверей, рыб и насекомых, которые посмеют им мешать. Испугавшись, Яцу-но ками и его подручные змеи «убежали и скрылись» [3, с. 42]. Очевидно, что, какими бы страшными ни были змеи, японцы исстари стремились относиться к ним как к божествам, лишь в ряде случаев демонстрируя при этом свою силу, что нашло отражение в эпических повествованиях о боге Сусаноо-но микото и смельчаке Матати из рода Яхадзу.

В японских историях непосредственно о мифическом любовнике акцент также делался на восприятии змея как божества. Более того, нередко указывалось точное название местности или горы, на которой обитал конкретный змей-бог. Связь змея с горой прослеживается при этом особенно четко, потому что в представлении японцев змеи были и, согласно синтоистской традиции, остаются до сих пор в ряде случаев хозяевами гор.

Наиболее древние японские истории на тему мифического любовника-божества горы известны еще по сводам «Кодзики» и «Нихонги». Так, во втором свитке «Кодзики» содержатся два эпизода, не связанных между собой сюжетно, но объединенных одним персонажем. Речь идет о боге «Оомононуси-но ками из Мива». В первом эпизоде этот бог обратился «стрелой, выкрашенной красным лаком» и воткнулся «в тайное место» избранной им девушки. Та вскрикнула, вынула стрелу и убежала домой. Но затем ночью положила стрелу себе в изголовье, и стрела превратилась в прекрасного юношу. Он женился на девушке, и от этого брака родилось женское божество, ставшее позднее супругой императора Дзимму, с которого начинается мифологическая история японского государства [8, с. 42]. Второй эпизод также повествует о боге Оомононуси-но ками, хотя имя его не называется, а лишь указывается на принадлежность горе Мива. Этот эпизод ориентирован на два важных фольклорных мотива, нередко следующих один из другого. Девушку по имени Икутамаёри-химэ начинает посещать незнакомец, они вступают в брачную связь, и она беременеет. Однако родители девушки пожелали узнать, кто же такой на самом деле избранник их дочери. Для этого мать учит девушку, что надо воткнуть иглу с ниткой в подол платья возлюбленного, чтобы на утро посмотреть, куда эта нить приведет. В данном случае длинная конопляная нитка приводит на гору Мива. Из этого становится ясно, что избранник девушки - божество/сын божества этой горы [8, с. 56-57]. Оба мотива - появление мифического любов- 
ника и выяснение истинного его облика благодаря иголке с ниткой - характерны практически для всех японских повествований на эту тему.

Отметим, что непосредственно из данных эпизодов не следует связь мифического любовника со змеем, но думается, что в древности особых пояснений не требовалось. Дело в том, что в японской традиции связь горы Мива (Оомива) с богом Оомононуси-но ками в облике змея была очевидна и общеизвестна. На это обращала внимание Л.М. Ермакова в комментариях ко второму свитку «Кодзики» [8, с. II5], а также к синтоистским песнопениям-норито: «Существует обширный цикл преданий о браках божества горы Мива с женщинами из окрестных сел. Таким образом, можно заключить, что в эпоху, предшествовавшую оформлению сводов, Оомононуси-но ками был божеством Ямато, духом горы Оомива, имевшим вид змея» [12, с. 248-249].

Эта же идея и сегодня лежит в основе истории создания храма Мива на его официальном сайте. В храме рассказывают не только об истинном облике божества этой священной горы, но и указывают места, куда следует класть подношения, а именно яйца - любимое лакомство бога-змея [І9]. Подтверждение восприятия бога горы Мива как змея можно обнаружить и в своде «Нихонги», в котором помещен эпизод о посещении по ночам богом Оомононуси-но ками девы по имени Ямато-тото-момосо-химэ. Дева, никогда не видавшая своего супруга днем, попросила того принять свой истинный облик, «чтобы лицезреть <...> прекрасную наружность при свете дня». Бог-супруг колебался, но потом решился показаться деве в своем истинном облике. Для этого он попросил ее заглянуть в шкатулку для гребней, куда спрячется на рассвете. Дева открыла шкатулку, «а там - прелестная маленькая змейка. Длина и толщина ее - вроде как у шнурка, которым одежду подвязывают» (пер. Л.М. Ермаковой). Дева от ужаса закричала, чем обидела бога-супруга. От стыда он тут же превратился в человека и сказал, что раз она навлекла на него позор, так и он ответит ей тем же. Он стал подниматься в небо, а она, засмотревшись на него, запрокинула голову, оступилась и села наземь. «Проткнула себе потаенное место палочками для еды и скончалась» [II, с. 213].

Здесь важно напомнить, что исследователь темы мифического любовника в славянском фольклоре Н.К. Козлова в уже упоминаемой нами работе «Восточнославянские былички о змее и змеях» (Омск, 200о) предложила подробную классификацию мотивов, связанную с этой темой. 
В основе этой классификации лежал принцип «подчинения» и «избавления». В первую большую группу исследователь предлагала относить тексты, в которых «мифическое существо вступает (пытается вступить) в любовные отношения с девушкой (женщиной). Она пассивна (не сопротивляется, не борется, выполняет все его требования и т. п.) - полностью попадает под его власть (беременеет, рожает, гибнет)». А во вторую - помещать тексты, в которых «активная роль принадлежит людям: девушка (женщина) (или родные, односельчане) сопротивляется, применяет оберег и избавляется от мифического существа» [5].

Если посмотреть на японский материал с точки зрения данной классификации, то становится очевидным: она прекрасно работает в общих положениях. При этом японский материал не дает столь широкой палитры вариантов и имеет одну отличительную особенность: контакт с мифическим любовником не вызывает ни у девушки, ни у ее родителей ужаса и отторжения. Они как бы априори воспринимают этот контакт как божественный. Хотя нельзя сказать, что сам мифический любовник, как следует из приведенного выше эпизода из свода «Нихонги», или рожденный от этой связи ребенок (змееныш) всегда ведут себя достойно по отношению к своим родственникам. В ранних текстах «божественное» не подразумевает однозначно «доброе». Идея «добра» мифического любовника найдет свое отражение позднее в фольклорных текстах, в основном в сказках.

А пока уместно вспомнить еще одну историю, приведенную в «Хитати-фудоки». Сохранилось повествование о брате и сестре, которые жили в деревне Убараки. К сестре по ночам стал приходить незнакомец, от которого она забеременела и родила змееныша. Мать и ее брат удивились, но не испугались, решив, что это сын божества. Однако змееныш стал расти и не помещался уже в сосуде, который ему дали. Мать попросила его вернуться к отцу, на что змееныш согласился, но затаил злобу. При расставании он ударом молнии убил своего дядю (но не мать), а сам собирался подняться в небо. Тогда мать швырнула в него кувшин, и он потерял божественную силу [3, с. 53-54]. Помимо интересного факта спокойного восприятия рождения у женщины змееныша как божественного ребенка, этот эпизод также демонстрирует связь «змей молния», характерный для японской традиции и следующий, вероятно, из традиционного восприятия змея как подателя влаги и повелителя стихии воды. Отметим также, что в японской культуре в этой связи прослеживается и третий 
компонент - стрела, на что обращала внимание Л.М. Ермакова [8, с. II5]. То есть появление в японских повествованиях о мифическом любовнике стрелы или молнии подразумевает змеиный облик этого любовника.

Что же касается «добропорядочности» любовника-змея, то, вероятно, это более поздние фольклорные интерпретации. Со временем японская народная традиция все больше тяготела к счастливому концу для повествований подобного рода. Японские исследователи отмечают бытование в фольклоре Японии большого числа произведений на эту тему. Как писал японский ученый Такэиси Такаси, «во многих районах Японии можно встретить народные истории о том, как девушка вышла замуж за змея, бога воды, а также истории о камне-змее, который предвещает дождь». Ряд повествований о замужестве девушки, как отмечает японский исследователь, напрямую связан с появлением «змеиных камней»: так боги-змеи, женившись на земной девушке, помогают людям и предупреждают их о дожде. В префектуре Нагано, например, рассказывают о камне, который напоминает по форме голову змея, который будто поднялся из-под земли. Согласно местным приметам, если камень становится влажным, будет дождь. И в префектуре Нара принято определять погоду по «змеиному камню»: если около него появляются желтые змейки, долго будет ясно, а вот если прочитать около камня буддийскую молитву о дожде, бог воды ее непременно услышит и дождь тут же пойдет [21, с. 848].

Счастливый финал истории о мифическом любовнике-змее можно обнаружить во многих произведениях повествовательного фольклора, например, в сказке архипелага Рюкю, известной как «Рукодельница и змей» [15, c. 213-215]. В ней юноша не посещает девушку по ночам, а просто насылает на нее дремоту, когда та занимается рукоделием. И тогда девушка видит сон, будто навстречу ей идет прекрасный юноша. По совету матери, которая заметила, что девушка стала медленнее вышивать, она воткнула иголку с длинной ниткой в лоб юноши, когда тот во сне вновь шел ей навстречу, и по этой нитке нашла под корнем старого дуба огромного змея. Но змей не испугал ни ее, ни мать, а попросил руки девушки, сказав, что он бог-хозяин здешних мест, и пообещав никогда не являться ей ни в каком ином облике, кроме человеческого. У этой сказки счастливый финал, она завершается свадьбой рукодельницы и змея, а также строительством храма у самых корней того самого дуба. 
Большое количество разных текстов, в которых прослеживается болееменее счастливый финал, дает возможность предположить, что приведенный в «Нихонги» эпизод о гибели девушки, которая испугалась, увидев своего возлюбленного в облике змейки, встречается в японской традиции не столь часто. И возникает ощущение, что наказание девушки следует не из-за злокозненности змея-бога, а из-за того, что, испугавшись, девушка поставила под сомнение божественную составляющую образа, не приняла мифического любовника однозначно божественным. В такой интерпретации просматриваются древние представления о богах синтоистского пантеона. И потому включение столь архаичных текстов в ранние письменные своды видится естественным и закономерным. Другое дело, например, поэтическая антология «Манъёсю». Будучи созданной в том же VIII в., антология представляет собой художественный текст и опирается на определенную эстетику и поэтическую образность. Потому не удивительно, что составители антологии несколько иначе взглянули на известный мотив, умышленно опустили трагическую составляющую, не пожелали выставить бога-змея в неприглядном свете.

Для примера можно привести повествование о мифическом любовнике, зафиксированное в двух древних японских памятниках - в географо-этнографическом своде фудоки провинции Хидзэн - «Хидзэн-фудоки» (между 732 и 740 гг.) и в поэтической антологии «Манъёсю» (около 750-х гг.). Оба памятника сохранили сведения об удивительной истории, случившейся с красавицей по имени Отохихимэко (Саёхимэ).

Сюжет о прекрасной Отохихимэко состоит из двух частей. И обе они подробно описаны в «Хидзэн-фудоки» в разделе, посвященном уезду Мацура. Будучи, прежде всего, географо-этнографическим сводом, этот памятник особое внимание уделял истории появления тех или иных топонимов и приводил бытовавшие в то время народные предания, связанные с их происхождением. В данном случае речь шла о горе Хирэфури, название которой понималось как «махать шарфом/платком». Интересно, что это реально существующая на юге Японии, на о. Кюсю в преф. Сагами (древняя земля Хидзэн) гора Кагамияма, у которой исторически было два названия. И второе как раз возвращает нас к событиям древней истории Японии.

Появление названия связано с эпизодом отъезда знатного воина Окура-но Садэхико по приказу императору в страну Мимана. Он снарядил корабли, а его возлюбленная Отохихимэко поднялась на вершину горы и 
долго махала (фури) ему вослед белым головным убором/шарфом-хирэ. Поэтому гору стали называть Хирэфури [3, с. I38].

Обращает на себя внимание то, что эта часть сюжета описана в «Хидзэн-фудоки» кратко и весьма скромными средствами, чего нельзя сказать о поэтической антологии «Манъёсю», в которой был помещен целый цикл песен, посвященных этому событию. Песни № 87I-875 с разной степени уверенности приписываются известному поэту Отомо-но Табито, песня № 868 принадлежит другому известному поэту Яманоэ-но Окура, а песня № 883 была сложена принцем Мисима «в подражание предыдущим песням» [9, с. 355-358].

В качестве примера можно привести одну из них (№ 87I):

Ожидающая человека издалече,

Мацура Саёхимэ, душою всей любя,

Здесь махала мужу шарфом белым,

В память этого

И названа гора!

(пер. А.Е. Глускиной) [9, с. 355].

Во всех других песнях также в поэтической манере рассказывалось о том, как девушка махала шарфом, отчего гора получила свое название. При этом в антологии «Манъёсю» красавица Отохихимэко появляется под именем Мацура Саёхимэ, на что в свое время обратил внимание переводчик и комментатор «Хидзэн-фудоки» К.А. Попов и пояснил, что речь идет об одном и том же лице [3, с. 252].

Песни антологии «Манъёсю», столь похожие друг на друга, совершенно игнорировали вторую часть сюжета о прекрасной Отохихимэко. Трудно сказать, чем точно руководствовались составители памятника и сами поэты, которые, конечно, не могли не знать продолжение этого предания. Тем более что время создания «Хидзэн-фудоки» и «Манъёсю» практически одно и то же, с разницей, может, всего в десяток лет. Вероятно, в данном случае составители антологии просто не хотели омрачать романтический образ верной девы, ведь наличие большого числа опоэтизированных народных преданий в этом памятнике не дает оснований говорить, что составители желали убрать из антологии ярко выраженную фольклорную 
составляющую. Образ страдающей от разлуки жены, провожающей мужа в дальний поход, заливаясь слезами, больше соответствовал «грусти и печали» древней японской поэзии. В качестве концовки для этого эпизода гораздо лучше подошла бы история о том, что, пребывая в печали, верная жена превратилась в камень на этой горе: А.Е. Глускина считала, что именно такое завершение было в одном из вариантов этого сказания [І, с. 594].

Если же следовать за «Хидзэн-фудоки», то история о красавице Отохихимэко имела совсем иное продолжение. Рассказывалось, что через пять дней к красавице начал по ночам приходить человек, внешностью похожий на ее мужа. Он проводил с ней ночь и на рассвете уходил. Женщина решила узнать, кто же этот незнакомец и прицепила длинную нитку за полу его одежды. Нитка вывела ее к озеру на вершине горы. Там спал огромный змей, «тело его было человеческое и лежало на дне озера, а голова была змеиной и лежала на берегу озера». Он очнулся и обратился к ней с просьбой спуститься в его дом. Служанка, что сопровождала женщину, закричала от ужаса и бросилась в деревню, чтобы позвать на помощь. Но, когда люди прибежали, они не нашли ни змея, ни Отохихимэко. «Тогда они взглянули на дно озера и увидели там тело человека. Это был труп Отохихимэко. Они сделали могилу южнее этой вершины и там погребли ее. Эта могила существует и в настоящее время» (Пер. К.А. Попова) [3, с. 138].

Особый интерес в данном контексте представляет песня змея, сложенная в размере японского пятистишья-танка. Она не была опубликована в основном японском издании древних фудоки г958 г. Однако комментатор этого издания Акимото Китаро собрал фрагменты, известные лишь по нескольким спискам памятников. Эти фрагменты представляют огромную ценность и могут свидетельствовать о том, что первоначально они входили в основные версии фудоки разных провинций [3, с. І3]. Так вот в одной из версий внимание акцентировалось на появлении названия горы/пика и истории о девушке, которая махала своим головным убором/шарфом с его вершины. Напомним, что именно эта история позднее и составила основу всех песен антологии «Манъёсю», связанных с этим сюжетом. В этой версии сохранилось еще и упоминание о неком болотистом озере на этой горе [3, с. I46]. В другом же фрагменте оказалась зафиксирована песня змея, в которой тот приглашает нашедшую его по нитке Отохихимэко (Отохимэко) спуститься к нему в это болотистое озеро: 
О, это ты, Отохимэко,

Из долины тростника!

Чтоб ночь еще одну

Мог провести с тобой,

Спускайся в дом мой!

(Пер. К.А. Попова) (Цит. по: [3, с. 253]).

Налицо развитие сюжета по принципу «подчинения», в котором разоблачение мифического любовника через нить с иглой приводит к гибели девушки. Однако еще раз повторим: несмотря на наличие историй с трагическим концом, большая часть повествований на эту тему все же тяготела к «божественному» восприятию происходящего.

При этом развитие темы мифического любовника-змея в японской литературе не ограничивалось произведениями древности. Несомненный интерес в свете нашей проблематики представляет и один из эпизодов средневековой «Повести о доме Тайра» («Хэйкэ-моногатари», XIII в.) [I4].

«Повесть» дошла до нас в большом количестве списков и вариантов. Некоторые из них короткие, а некоторые столь обширны, что их части получили заголовки и стали существовать как самостоятельные произведения. Наличие такого большого числа вариантов свидетельствует о том, что «Повесть о доме Тайра» имела народные истоки. И это без труда можно обнаружить в тексте «Повести»: в повествование постоянно вплетаются истории явно фольклорного происхождения. Первоначально «Повесть» исполнялась устно бродячими певцами бива-хоси, а литературная запись приписывается буддийскому монаху. Спустя столетие Кэнко-хоси, автор известных «Записок от скуки», напишет: «...монах Юкинага создал “Повесть о доме Тайра” и обучил слепца по имени Сёбуцу рассказывать эту повесть. А Сёбуцу, уроженец восточных провинций, расспрашивал воинов-самураев о ратных делах и о них самих и помог Юкинага все это описать. От рождения обладал Сёбуцу исполнительским даром; нынешние певцы-сказители все ему подражают» (пер. В.Н. Горегляда) [2, с. 232].

Наиболее полный текст «Повести» состоит из тринадцати свитков и описывает события, происходившие с героями на протяжении тридцати лет. Это сказание о противостоянии двух знатных родов - Тайра и Минамото - содержит множество драматических и даже трагических эпизодов. 
Один из них, представляющий интерес в свете нашей проблематики, - это уход воинов Тайра, гонимых воинами Минамото, из столицы и их скитание по чужим краям, где им «пристанищем служили поля и равнины» (свиток восемь). Казалось, что на какое-то время Тайра обрели спокойствие в краю Бунго (о. Кюсю), однако и в те далекие края пришло распоряжение от владельца земель. В нем говорилось о том, что следует прогнать Тайра. «Непонятно и странно, - говорилось в нем, - что самураи острова Кюсю приютили и ласкают таких отщепенцев! Вам, жители земель Кюсю, не пристало держать сторону Тайра. Надлежит вам дружно прогнать их прочь!» (пер. И. Львовой). Получив такое строгое распоряжение от отца, сын его, выполнявший роль наместника, поручил исполнить этот приказ местному жителю, самураю по имени Карэёси Огата. Как гласит «Повесть», «сей Карэёси вел свой род от страшного существа» [I4, с. 36I].

Далее в повествование мастерски вплетена история с известным мотивом. Рассказывается, что в краю Бунго, где сейчас как раз и происходила история о преследовании Тайра, в селении Катаяма жила девушка, которую по ночам стал посещать неизвестный мужчина. Вскоре она забеременела, и тогда мать посоветовала ей прикрепить к его одежде «какую-то отмету» и последовать за ним. Девушка воткнула иголку с нитью в воротник своего любовника и пошла за ним следом. В результате она пришла к огромной пещере, услышала стоны и заговорила с ее обитателем. Тот ответил, что боится показаться ей в своем истинном виде. «Возвращайся домой! Во чреве ты носишь мальчика. Когда он вырастет, опояшется мечом и возьмет лук и стрелы, не будет равных ему в силе воинов ни на острове Кюсю, ни на островах Цусима и Ики», - сказал он ей из глубины пещеры. Однако девушка настаивала, что хочет увидеть его. И тогда из пещеры выполз змей «столь огромный, что сама земля под ним содрогалась». Девушка чуть не лишилась чувств, а сопровождавшие ее слуги закричали и бросились прочь. Спустя время девушка родила сына, которого взял на воспитание ее отец. Мальчика нарекли Дайта, но все его звали Дайта-заусенец, потому что у него на руках и ногах были всегда заусенцы-трещины. «Змей же был не кто иной, как бог Такатио, которому поклоняются в краю Хюга», - резюмирует «Повесть». И добавляет: «От этого Дайты-заусенца и вел свой род в пятом колене Карэёси Огата». И далее: «Немудрено, что, будучи потомком столь страшного человека, он лживо выдал приказ пра- 
вителя земли Бунго за императорский манифест... (пер. И. Львовой) [I4, c. $36 \mathrm{I}-362]$.

В этом эпизоде, имевшем печальные последствия для рода Тайра, внимание привлекают несколько важных для нас деталей. Вновь события происходят на острове Кюсю, причем этот факт не только не скрывается, а даже детализируется - упоминается селение Катаяма. Здесь уместно вспомнить, что история о прекрасной Отохихимэко также происходила в тех же краях, что зафиксировалось в фудоки провинции о. Кюсю - «Хидзэн-фудоки». Можно вспомнить и сказку «Рукодельница и змей», бытовавшую на островах Рюкю, т. е. в непосредственной близости от о. Кюсю. В связи с этим можно предположить, что при всей распространенности мотива в Японии он тяготел к южным островам.

Также вновь речь идет о змее-божестве - хозяине тех мест. При этом ребенок, рожденный от змея-божества, это уже не змееныш, а человек. Он обладает великими способностями, что передается и его потомкам, среди которых называется и реальная историческая личность - Карэёси Огата. Если вспомнить историю о божественном ребенке-змееныше, который никак кроме как своими бесчинствами не прославился, можно говорить о том, что теперь речь идет о рождении не бога, а героя. Божественное трансформировалось в героическое. При этом надо отметить, что стала проявляться и определенная боязнь, чего не было в древних текстах. Не случайно поэтому в «Повести» дважды дается определение «страшный», когда речь идет о происхождении Карэёси. Змеиное происхождение теперь явно перевешивает божественную составляющую, и потому ставится знак равенства между таким происхождением и лживостью, непорядочностью характера. «Нечеловеческое» происхождение героя однозначно рассматривается «Повестью» как причина его предательских поступков. В такой трактовке образа четко прослеживается отношение к этому герою со стороны неизвестного автора. Нам же сейчас важно отметить, что, согласно средневековой интерпретации, от союза женщины и змея рождается герой, наделенный большими воинскими способностями.

Примечательно, что примерно в это же время схожий сюжет был зафиксирован в корейских исторических хрониках. Так, в «Самгук юса» (XIII в.) рассказывалось о необычном рождении Кён Хвона (Чин Хвона), героя поздней корейской мифологии, основателя удельного государства 
Позднее Пэкче, существовавшего с 892 по 936 гг. в период феодальной раздробленности Силла. Согласно древнему преданию, к девушке из богатой семьи стал по ночам ходить «какой-то мужчина в темно-лиловом платье». Отец посоветовал ей воткнуть ему в платье иголку с длинной ниткой. Наутро они нашли иглу в спине большого земляного червя под северной оградой. Девушка забеременела и родила сына, который потом «назвался государем и утвердил столицу в Вансане и правил сорок три года». В другом эпизоде о Кён Хвоне герою дается такая характеристика: «..вырос подлинным богатырем. Дух его был неукротим. Среди обычных людей он не ведал равных» [6, с. 6I]. То есть речь также идет о рождении от союза женщины и червя (змея) истинного героя и воина.

Интересно, что приведенный эпизод в нашей науке уже был предметом исследования. А.Ф. Троцевич обращала внимание на пурпурный цвет предметов в корейской мифологии и связывала это с проявлением солярного культа. Правда, в ее переводе к дочери богатого человека является «мужчина в пурпурном платье» (для сравнения: в переводе Л.Р. Концевича о Кён Хвоне - в темно-лиловом; не исключено, что имеется в виду один и тот же цвет). Отец советует ей воткнуть иголку с ниткой в его одежду, что она и делает. Наутро игла оказывается воткнутой в туловище большого земляного червя [I7, c. I07]. Ребенок, рожденный от этой связи, и был герой Чин Хвон (Кён Хвон). В свое время М.И. Никитина, подробно занимаясь солярными культами в корейской мифологии, высказывала предположение, что земляной червь выступает в качестве солярного оборотня, а с помощью иголки ему возвращают истинный облик [Іо, с. 229].

Мы же со своей стороны напомним, что стрела, которая вонзилась в «тайное место» полюбившейся японскому богу горы Мива, имеющему облик змея, девушки, также была красного цвета. То есть японская традиция в древности активно оперировала такой мифологической связкой как «божество - змей - стрела/молния - красный цвет», в которой все составляющие можно определить как божественные и солярные, а следовательно, связанные с плодородием и продуцирующей магией. В средневековой же литературе архаические представления были несколько переосмыслены, и распространение получила связка «ребенок бога-змея - воин-герой». И если вспомнить, что большинство историй о мифическом любовнике, который на самом деле был богом-змеем, бытовало на южных островах 
Японии и на архипелаге Рюкю, позднее вошедшем в состав Японии, то корейский материал вполне вписывается в идею южного распространения данной вариации этого мотива и дает еще один повод говорить о тесных корейско-японских фольклорно-мифологических связях в период древности и раннего Средневековья.

Таким образом, очевидно, что фольклорный мотив о мифическом любовнике, широко распространенный в разных регионах мира, оказался чрезвычайно продуктивным для японской традиции, как фольклорной, так и литературной. Более того, истории на эту тему нашли свое отражение в государственно значимых памятниках и даже вплетались в «жизнеописания» героев мифологической японской истории. При этом совершенно очевидным было влияние на эти тексты архаических представлений о змее, как боге плодородия, подателе влаги, хранителе дома. Эти архаические представления продолжают бытовать и сегодня в современной Японии. Обращает на себя внимание и «тяготение» темы мифического любовника к определенной части Японии. Это районы, которые, с одной стороны, были местом зарождения и становления японской государственности, с другой - наиболее удобным местом для контактов с соседними народами и культурами. Богатый японский материал на тему мифического любовника чрезвычайно важен как для типологических обобщений, так и для более глубокого исследования фольклорно-мифологических основ традиционной японской культуры.

\section{Список литературы}

I Глускина A.Е. Комментарий // Манъёсю («Собрание мириад листьев») / пер. с яп., предисл., коммент. А.Е. Глускиной. Т. І-3. М.: Наука. ГРВЛ, І97І. Т. І. C. $521-626$. Горегляд В.Н. Японская литература VIII-XVI вв. Начало и развитие традиций. СПб.: Центр «Петербургское востоковедение», І997. 416 с.

3 Древние фудоки (Хитати, Харима, Бунго, Хидзэн) / пер., предисл. и коммент. К.А. Попова. М.: Наука, г969. 340 с.

4 Иванов В.В. Змей // МНМ. Т. г. С. 468-470.

5 Козлова Н.К. Восточнославянские былички о змее и змеях. Мифический любовник. Указатель сюжетов и тексты / под ред. Ю.И. Смирнова. Омск: Изд-во ОмГПУ, 2000. URL: https://www.studmed.ru/kozlova-nk-vostochnoslavyanskiebylichki-o-zmee-i-zmeyah-mificheskiy-lyubovnik-ukazatel-syuzhetov-i-teksty_ f8788290064.html (дата обращения: I7.07.2019). 
Корейские предания и легенды из средневековых книг / пер. с ханмуна; сост. и коммент Л. Концевича; вступит. ст. Б. Рифтина; стихи в пер. Е. Витковского; худож. А. Костин. М.: Худож. лит., І980. 286 с.

7 Кодзики - Записи о деяниях древности. Свиток г-й Мифы / пер., коммент. Е.М. Пинус. СПб.: ШАР, І993. 320 с.

8 Кодзики - Записи о деяниях древности. Свиток 2-й и 3-й / пер., предисл. и коммент. Л.М. Ермаковой, А.Н. Мещерякова. СПб.: ШАР, г994. 256 с.

9 Манъёсю («Собрание мириад листьев») / пер. с яп., предисл., коммент. А.Е. Глускиной. Т. І-3. М.: Наука. ГРВЛ, І97І-І972. Т. І. 680 с. Никитина М.И. Древняя корейская поэзия в связи с ритуалом и мифом. М.: Наука, ГРВЛ, І982. 328 с. Нихон сёки - Анналы Японии: в 2 т. / пер. и коммент. Л.М. Ермаковой и А.Н. Мещерякова. СПб.: Гиперион, І997. Т. г: Свитки I-XVI. 496 с. Норито. Сэммё / пер. со старояпонского Л.М. Ермаковой. М.: Наука. ГРВЛ, I99I. 299 C.

Попов К.А. Антропонимический комментарий // Древние фудоки (Хитати, Харима, Бунго, Хидзэн) / пер., предисл. и коммент. К.А. Попова. М.: Наука, І969. C. $237-264$.

I4 Повесть о доме Тайра / пер. со старояпон. И. Львовой. Стихи в пер. А. Долина. М.: Худож. лит., І982. 768 c.

I5 Поле заколдованных хризантем. Японские народные сказки / пер. с яп. Н. Фельдман, А. Садоковой; обраб. Н. Ходза. М.: Искона, г994. 240 с.

I6 Пропn В.Я. Русский героический эпос. М.: Лабиринт, І999. 638 с.

I7 Троцевич А.Ф. Миф и сюжетная проза Кореи. СПб.: Центр «Петербургское востоковедение», 1996.208 c.

I8 Кавагути Кэндзи. Нихон-но камисама дзитэн. Ёми токи [Энциклопедия японских синтоистских божеств. Чтение, толкование]. Токио: Касивасёбо:, 200I. 558 с.

I9 Оомива-дзиндзя [Храм Оомива]. URL: http://oomiwa.or.jp/ (дата обращения: 19.07.2019).

20 Судзуки То: дзо. Нихон нэнтю: гё: дзи дзитэн [Энциклопедия праздников года]. Токио: Кадокава сюппан, І979. 422 с.

2I Такэиси Такаси. Хэби иси [Змеиный камень] // Нихон сэцува дэнсэцу дайдзитэн [Энциклопедия поучительных рассказов и преданий] / сост. Симура Кунихиро, Сува Харуо. Токио: Бэнсэй, 200о. С. 848.

22 Хагивара Хидэсабуро. Сакаи то цудзи-но ками [Боги границ и перекрестков]. Серия: Мэ-дэ миру миндзоку ками [Народные божества, увиденные своими глазами]. Токио: То: кё: бидзюцу, І988. І26 с.

23 Ямаути кинрин. Онсирадзуно хэби [Запрет звенеть колокольчиком в храме. Неблагодарная змея] // Кавагоэ-но дэнсэцу [Легенды Кавагоэ]. Переск., иллюстр. Исэхара Сё:дзи. Кавагоэ: Кавагоэси кё: икуиинкай, 2ооо. С. 8-9. 
Ятани Маюми. Хэби [Змей] // Нихон сэцува дэнсэцу дайдзитэн [Энциклопедия поучительных рассказов и преданий]. Сост. Симура Кунихиро, Сува Харуо.

Токио: Бэнсэй, 200о. С. 847-848.

\section{References}

I Gluskina A.E. Kommentarii [Commentary]. Man”esiu ("Sobranie miriad listiev"). [The Man'yōshū (“Collection of Ten Thousand Leaves”)], transl. from Japanese, foreword, comm. by A.E. Gluskina. Vol. I-3. Moscow, Nauka. GRVL Publ., I97I, vol. I, pp. 52I-626. (In Russ.)

2 Goreglyad V.N. Iaponskaia literatura VIII-XVI vv. Nachalo i razvitie traditsii [Japanese literature of the $8^{\text {th }}-16^{\text {th }}$ centuries. The beginning and the development of the tradition]. St. Petersburg, Tsentr "Peterburgskoe vostokovedenie" Publ., I997. 4I6 p. (In Russ.) Drevnie fudoki (Khitati, Kharima, Bungo, Khidzen) [Ancient fudoki (Hitachi, Harima, Bungo, Hizen)], transl., foreword, and comm. by K.A. Popov. Moscow, Nauka Publ., I969. 340 p. (In Russ.)

4 Ivanov V.V. Zmei [Serpent]. MNM, vol. I, pp. 468-470. (In Russ.)

5 Kozlova N.K. Vostochnoslavianskie bylichki o zmee i zmeiakh. Mificheskii liubovnik. Ukazatel' siuzhetov i teksty [East Slavic "bylichki” about a serpent and serpents. Mythical lover. Reference of plots and texts], ed. Yu.I. Smirnov. Omsk, Izd-vo OmGPU Publ., 200o. Available at: https://www.studmed.ru/kozlova-nk-vostochnoslavyanskiebylichki-o-zmee-i-zmeyah-mificheskiy-lyubovnik-ukazatel-syuzhetov-i-teksty_ f8788290064.html (Accessed I7 July 20I9). (In Russ.)

$6 \quad$ Koreiskie predaniia i legendy iz srednevekovykh knig [Korean tales and legends from medieval books], transl. from hanmun., comp. and comm. by L. Kontsevich; foreword by B. Riftin; poems transl. by E. Vitkovsky; design by A. Kostin. Moscow, Hudozhestvennaya literatura Publ., I980. 286 p. (In Russ.)

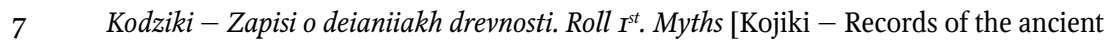
deeds], transl., comm. by E.M. Pinus. St. Petersburg, SHAR Publ., I993. 320 p. (In Russ.)

8 Kodziki - Zapisi o deianiiakh drevnosti. Roll $2^{\text {nd }}$ and $3^{\text {rd }}$ [Kojiki - Records of the ancient deeds], transl., comm. by L.M. Ermakova, A.N. Meshcheryakov. St. Petersburg, SHAR Publ., I994. 256 p. (In Russ.)

9 Man"esiu ("Sobranie miriad listiev") [The Man'yōshū ("Collection of Ten Thousand Leaves”)], transl. from Japanese, foreword, comm. by A.E. Gluskina. Vol. I-3. Moscow, Nauka. GRVL Publ., I97I-I972. Vol. I. 680 p. (In Russ.) Nikitina M.I. Drevniaia koreiskaia poeziia v sviazi s ritualom i mifom [Ancient Korean poetry in connection with ritual and myth]. Moscow, Nauka, GRVL Publ., I982. 328 p. (In Russ.) 
Nihon syoki - Annaly Iaponii: $v 2 t$. [Nihon Shyoki - Japanese annals: in 2 vols.], transl. and comm. by L.M. Ermakova and A.N. Meshcheryakov. St. Petersburg, Giperion Publ., I997. Vol. I: Rolls I-XVI. 496 p. (In Russ.)

Norito. Semmyo [Norito. Semmyo], transl. from old Japanese by L.M. Ermakova. Moscow, Nauka. GRVL Publ., I99I. 299 p. (In Russ.)

Popov K.A. Antroponimicheskii kommentarii [Anthroponymic commentary]. Drevnie fudoki (Khitati, Kharima, Bungo, Khidzen) [Ancient fudoki (Hitachi, Harima, Bungo, Hizen)], transl., foreword, comm. by K.A. Popov. Moscow, Nauka Publ., I969, pp. 237-264. (In Russ.)

4 Povest' o dome Taira [The Tale of the Heike], transl. from old Japanese by I. Lvova. Poems transl. by A. Dolin. Moscow, Hudozhestvennaya literatura Publ., I982. 768 p. (In Russ.)

Pole zakoldovannykh khrizantem. Iaponskie narodnye skazki [The field of enchanted chrysanthemums. Japanese folk tales], transl. from Japanese by N. Feldman,

A. Sadokova, N. Hoza. Moscow, Iskona Publ., I994. 240 p. (In Russ.)

Propp V.Ia. Russkii geroicheskii epos [Russian heroic epic literature]. Moscow, Labirint Publ., I999. 638 p. (In Russ.)

Trotsevich A.F. Mif i siuzhetnaia proza Korei [Korean myth and narrative prose]. St. Petersburg, Tsentr "Peterburgskoe vostokovedenie” Publ., I996. 208 p. (In Russ.) Kavaguti Kendzi. Nikhon-no kamisama dziten. Yomi toki [The encyclopedia of Japanese Shinto gods. Reading, definition]. Tokyo, Kashivashyobo Publ., 200I. 558 p.

(In Japanese)

9 Oomiva-dzindzia [Oomiva Dzindzia]. Available at: http://oomiwa.or.jp/ (Accessed I9 July 20I9). (In Japanese)

Sudzuki To: dzo. Nikhon nentiu: ge: dzi dziten [The encyclopedia of yearly holidays]. Tokyo, Kadokava Shuppan Publ., I979. 422 p. (In Japanese)

Takeisi Takasi. Hebi ishi [Serpent's stone]. Nikhon setsuva densetsu daidziten [The encyclopedia of instructive short stories and tales], comp. by Shimura Kunihiro, Suwa Haruo. Tokyo, Bensei Publ., 2000. P. 848. (In Japanese)

2 Khagivara Khidesaburo. Sakai to tsudzi-no kami [Gods of boundaries and crossroads]. Series: Me-de miru minzoku kami [Folk gods, seen for oneself]. Tokyo, Tokyo bidzutsu Publ., I988. I26 p. (In Japanese)

23 Iamauti kinrin. Onshirazuno hebi [Prohibitions on ringing the bell in a temple. The ungracious serpent]. Kavagoe-no densetsu [Kavagoe legends]. Told, illustr. by Isehara Syoudzi. Kavagoe, Kavagoeshi kyouikuiinkai Publ., 2000, pp. 8-9. (In Japanese) Iatani Maiumi. Hebi [Serpent]. Nihon setsuva densetsu daidziten [Encyclopedia of instructive short stories and tales], comp. by Shimura Kunihiro, Suwa Haruo. Tokyo, Bensei Publ., 200o, pp. 847-848. (In Japanese) 